\title{
Effect of Egg Shell Powder on Strength Behaviour of Concrete
}

\author{
R.Venkata Krishnaiah, P. Dayakar, S.J. Mohan
}

\begin{abstract}
The study of strength behaviour of M20 grade concrete, by exchanging the cement partly by powder of egg shell, for which an experimental tests were carried out and the effect of egg shell powder $(0 \%, 5 \% .10 \%, 15 \%)$ on compressive strength characteristics were studied. The result of this present investigation shows that the replacement of 5\% of cement with egg shell powder attains the maximum compressive strength. The best and economical percentage exchange of replacement of powder of egg shell (ESP) with cement is about $5 \%$ and also reduces the cost of concrete with the use of powder of egg shell, which is available freely as raw material and then it is grinded well to make powder.
\end{abstract}

The egg shell is available from municipal solid waste and is mixed in powder form in concrete by exchanging the cement and is found that 5\% replacement is very effective in the improvement of strength properties when compared to the conventional concrete. Also the exchangement of 5\% ESP in cement gives higher split tensile strength as compared to other cement ingredient mixtures.

In this study, it is fixed that 0.45 is the $w / c$ ratio and it produces medium degree of workability which is suitable for most of the concrete mixtures on site. The addition of eggshell powder as filler in concrete has improved the strength of concrete and also improved and better split tensile strength.

Key words: Egg Shell Powder, Comprssive Strength, Split Tensile Strength

\section{INTRODUCTION}

To meet the fast growing industrial and construction development in the country, there is a huge consumption of cement and its various ingredients of mixtures[1],[3],[5]. Concrete is a construction material which has relatively high strength in compression, but lower strength in tension.

For more varieties of reasons, there is no stability in infrastructural construction industry. Firstly, because of utilization of very high volumes of natural resources which are sustaining for next generations. Secondly, the binder material called cement in concrete, the production of which leads to greenhouse gas emissions and that are causing global warming and climate change[2 ],[4],[6]. Thirdly, there is a lack of durability in many concrete structures, which are wasting the natural resources and the major component of

Revised Manuscript Received on July 22, 2019.

Dr R.Venkata Krishnaiah, Associate Professor, Department of Civil Engineering, Bharath Institute Of Education And Research, Chennai, Tamil Nadu.Email : venkatapec@gmail.com

P. Dayakar, Associate Professor, Department of Civil Engineering, Bharath Institute Of Education And Research, Chennai, Tamil Nadu.

Email : dayakarpitti@yahoo.co.in

Dr. S.J. Mohan, Professor, Department of Civil Engineering, Bharath Institute Of Education And Research, Chennai , Tamil Nadu. Email : mohansjm@yahoo.com concrete is cement and it produces carbon dioxide about $1000 \mathrm{~kg}$ of CO2 emitted for every $1000 \mathrm{~kg}$ production cement. As of 2001, the world wise cement production is contributed about 7.5\% CO2 emission[7],[9],[11] , it is mainly due to the burning of limestone and clay at $1600^{\circ} \mathrm{C}$. There fore the production of cement is directly related to $\mathrm{CO} 2$ emission.

\section{EXPERIMENTAL STUDY}

Fundamental tests are done according to IS Standard to decide the physical properties of fine and coarse totals. For fine total, trial of explicit gravity and fineness modulus are discovered and for coarse total, trial of explicit gravity, sway esteem, squashing worth and Los Angeles are led. Testing of hardned cement is done according to IS benchmarks to decide the compressive quality of cement at 7 days and 28 days directed.

Table 1.Physical properties of cement

\begin{tabular}{|l|l|l|}
\hline Sl.no & Properties & Test results \\
\hline 1. & Specific gravity & 3.15 \\
\hline 2. & Fineness & $7.33 \%$ \\
\hline 3. & Normal consistency & $37 \%$ \\
\hline 4. & Initial setting time & $48 \mathrm{~min}$ \\
\hline
\end{tabular}

Table 2. Tests of fine aggregate

\begin{tabular}{|c|c|c|}
\hline Sl.no & Test & Result \\
\hline 1. & Specific gravity & 2.55 \\
\hline 2. & Fineness Modulus & 3.25 \\
\hline
\end{tabular}

\section{RESULTS}

\section{A. Compression test for cubes}

The concrete is filled in the mould and compacted properly to remove the voids. After 24 hours, specimens are removed from the moulds and the specimens are immersed in water for curing. Then, after 7 days curing, the specimens are tested by compression testing machine. [19],[21],[23]

Compressive strength of concrete cube is the maximum Compressive strength $=$ Maximum load/area

Table -3 Compressive strength of cubes for 7 days 


\begin{tabular}{|c|c|c|c|c|}
\hline Grade & $\begin{array}{c}\% \text { of } \\
\text { replacem } \\
\text { ent }\end{array}$ & $\begin{array}{c}\text { Sample } \\
1\end{array}$ & Sample 2 & $\begin{array}{c}\text { Avg.compressi } \\
\text { ve strength for } \\
7 \text { days } \\
\left(\mathrm{N} / \mathrm{mm}^{2}\right)\end{array}$ \\
\hline & $0 \%$ & 10.10 & 8.35 & 9.225 \\
\hline $\mathrm{M} 2 \mathrm{O}$ & $5 \%$ & 8.65 & 9.35 & 9.00 \\
\hline & $10 \%$ & 7.55 & 9.16 & 8.35 \\
\hline & $15 \%$ & 6.35 & 7.25 & 6.9 \\
\hline
\end{tabular}

Figure - 1 Graphical Representation of Compressive Strength of Cubes-7 days

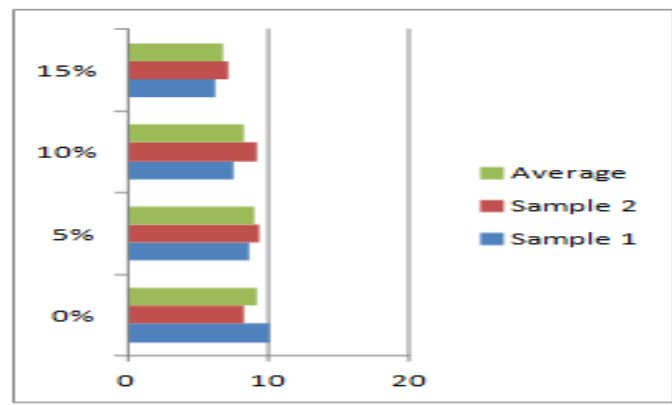

$\mathrm{x}$-axis: Compressive strength, $\mathrm{y}$-axis: \% of replacement of egg shell powder.

Table - 4 Compressive strength on cubes for 28 days

\begin{tabular}{|c|c|c|c|c|}
\hline Grade & $\begin{array}{c}\% \text { of } \\
\text { replace } \\
\text { ment }\end{array}$ & Sample 1 & Sample 2 & $\begin{array}{c}\text { Avg.compres } \\
\text { sive strength } \\
\text { for 7 days } \\
\left(\mathrm{N} / \mathrm{mm}^{2}\right)\end{array}$ \\
\hline & $0 \%$ & 21.30 & 22.63 & 21.96 \\
\hline $\mathrm{M} 20$ & $5 \%$ & 25.26 & 27.34 & 26.30 \\
\hline & $10 \%$ & 22.10 & 24.15 & 23.12 \\
\hline & $15 \%$ & 20.20 & 22.17 & 21.18 \\
\hline
\end{tabular}

Figure - 2 Graphical Representation of Compressive Strength of Cubes-28 days

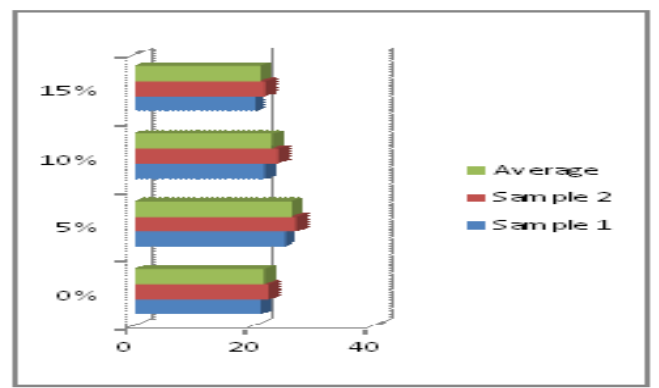

$\mathrm{x}$-axis: Compressive strength, $\mathrm{y}$-axis: \% of replacement of egg shell powder.

\section{B. Split Tensile Strength Test on Concrete Cylinders}

It is very important to determine the tensile strength of concrete as to determine the load at which the concrete members may crack.

Table 5 - Split Tensile strength on cubes for 7 days

\begin{tabular}{|c|c|c|c|c|}
\hline Grade & $\begin{array}{c}\% \text { of } \\
\text { replaceme } \\
\text { nt }\end{array}$ & $\begin{array}{c}\text { Sampl } \\
\text { e 1 }\end{array}$ & $\begin{array}{c}\text { Sampl } \\
\text { e 2 }\end{array}$ & $\begin{array}{c}\text { Avg.compressiv } \\
\text { e strength for 7 } \\
\text { days (N/mm } \mathbf{m m}^{2}\end{array}$ \\
\hline & $0 \%$ & 2.52 & 3.45 & 2.45 \\
\hline $\mathrm{M} 20$ & $5 \%$ & 2.71 & 2.45 & 2.98 \\
\hline & $10 \%$ & 1.98 & 1.7 & 1.84 \\
\hline & $15 \%$ & 1.5 & 1.35 & 1.4 \\
\hline
\end{tabular}

Figure - 2 Graphical Representation of Split Tensile Strength of Cylinders-7 days

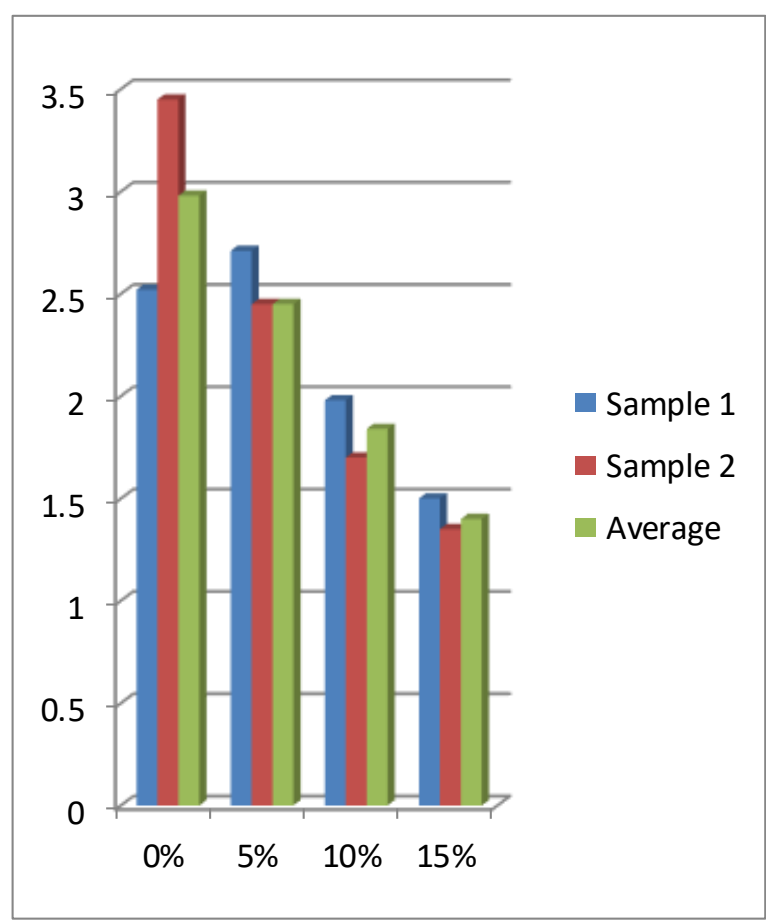

$\mathrm{x}$-axis: \% of replacement of egg shell powder, $\mathrm{y}$-axis: Tensile strength value.

\section{CONCLUSION}

Egg shell acquired from civil strong squanders is by making powder and included different rates for bond substitution and it is resolved that the substitution of bond by $5 \%$ egg shell powder is expanded by $19.76 \%$ in 28 days compressive quality when contrasted with the customary concrete [31],[33]. Likewise it is resolved that the substitution of bond by $5 \%$ egg shell powder is expanded by $21 \%$ in 7 days split rigidity when contrasted with the ordinary concretet.

The water bond proportion of 0.45 produces medium level of usefulness which is reasonable for the vast majority of the solid throwing nearby. It is seen that there is an improvement of compressive quality of cement by the expansion of eggshell powder which is going about as a filler in the solid. Concrete with the expansion of $5 \%$ eggshell powder demonstrated the most noteworthy compressive quality[32],[34]. At 28 days relieving. So also, concrete with expansion of $5 \%$ eggshell powder demonstrated the most noteworthy split rigidity. 


\section{REFERENCES}

1. Iyappan L., Dayakar P., Identification of landslide prone zone for coonoortalukusing spatial technology, International Journal of Applied Engineering Research,V-9,I-22,PP-5724-5732,Y-2014.

2. Kumar J., Sathish Kumar K., Dayakar P.,Effect of microsilica on high strength concrete, International Journal of Applied Engineering Research,V-9,I-22,PP-5427-5432,Y-2014.

3. Dayakar P., Vijay Ruthrapathi G., Prakesh J., Management of bio-medical waste, International Journal of Applied Engineering Research,V-9,I-22,PP-5518-5526,Y-2014.

4. Swaminathan N., Dayakar P., Resource optimization in construction projec2,9. International Journal of Applied Engineering Research,V-9,I-22,PP-5546-5551,Y-2014.

5. Venkat Raman K., Dayakar P., Raju K.V.B.,An experimental study on effect of cone diameters in penetration test on sandy soil, International Journal offo. Civil Engineering and Technology,V-8,I-8,PP-1581-1588,Y-2017.

6. Saritha B., Chockalingam M.P.,Photodradation of malachite green DYE using1 TIO2/activated carbon composite,International Journal of Civil Engineering and Technology,V-8,I-8,PP-156-163,Y-2017

7. Shendge R.B., Chockalingam M.P., Saritha B., Ambica A.,Swat modelling fo 22 sediment yield: A case study of Ujjani reservoir in Maharashtra, India,International Journal of Civil Engineering and3. Technology,V-9,I-1,PP-245-252,Y-2018

8. Chockalingam M.P., Balamurgan V.,Modernisation of an existing urban road-sector in Chennai, a case study report,International Journal of Civi44. Engineering and Technology,V-8,I-8,PP-1457-1467,Y-2017

9. Saritha B., Chockalingam M.P.,Adsorption study on removal of basic dye by modified coconut shell adsorbent, International Journal of Civil Engineering and Technology,V-8,I-8,PP-1370-1374,Y-2017

10. Saritha B., Chockalingam M.P.,Adsorptive removal of heavy metal chromium from aqueous medium using modified natural adsorbent,International Journal of Civil Engineering and Technology,V-8,I-8,PP-1382-1387,Y-2017

11. Chockalingam M.P., Palanivelraja S.,Retrospective analysis of a theoretiçt model used for forecasting future air quality near the north Chennai thermal power plant,International Journal of Civil Engineering apd Technology,V-8,I-8,PP-1457-1467,Y-2017

12. Saritha B., Chockalingam M.P.,Photodegradation of methylene blue dye in aqueous medium by $\mathrm{Fe}-\mathrm{AC} / \mathrm{TiO} 2$ Composite,Nature Environment and Pollution Technology,V-17,I-4,PP-1259-1265,Y-2018

13. Shendge R.B., Chockalingam M.P., Kaviya B., Ambica A.,Estimates potential evapotranspiration rates by three methods in upper Bhima Basin, In Maharashtra, India,International Journal of Civil Engineering a Technology,V-9,I-2,PP-475-480,Y-2018

14. Shendge R.B., Chockalingam M.P.,The soil and water assessment tool f Ujjani Reservoir,International Journal of Mechanical Engineering an Technology,V-9,I-2,PP-354-359,Y-2018

15. Shendge R.B., Chockalingam M.P.,A review on soil and water assessment tool,International Journal of Mechanical Engineering Technology,V-9,I-2,PP-347-353,Y-2018

16. Sachithanandam P., Meikandaan T.P., Srividya T.,Steel framed multi stofey residential building analysis and design,International Journal of Appliet Engineering Research,V-9,I-22,PP-5527-5529,Y-2014

17. Meikandaan T.P., Ramachandra Murthy A.,Study of damaged RC beams repaired by bonding of CFRP laminates,International Journal of Civil Engineering and Technology,V-8,I-2,PP-470-486,Y-2017

18. Meikandaan T.P., Ramachandra Murthy A.,Retrofittng of reinforced concrete beams using GFRP overlays,International Journal of Civil Engineering and Technology,V-8,I-2,PP-423-439,Y-2017

19. Meikandaan T.P., Ramachandra Murthy A.,Flexural behaviour of RC beam wrapped with GFRP sheets,International Journal of Civil Engineering and Technology,V-8,I-2,PP-452-469,Y-2017

20. Meikandaan T.P., Murthy A.R.,Experimental study on strengthening of rc beams using glass Fiber,International Journal of Civil Engineering and Technology,V-9,I-11,PP-959-965,Y-2018

21. Meikandaan T.P., Hemapriya M.,Use of glass FRP sheets as external flexural reinforcement in RCC Beam,International Journal of Civil Engineering and Technology,V-8,I-8,PP-1485-1501,Y-2017

22. Saraswathy R., Saritha B.,Planning of integrated satellite township at Thirumazhisai,International Journal of Applied Engineering Research,V-9,I-22,PP-5558-5560,Y-2014

23. Saritha B., Ilayaraja K., Eqyaabal Z.,Geo textiles and geo synthetics for soil reinforcement,International Journal of Applied Engineering Research,V-9,I-22,PP-5533-5536,Y-2014

24. Ambica A., Saritha B., Changring G., Singh N B., Rajen M., Salman Md.,Analysis of groundwater quality in and around Tambaram taluk, Kancheepuram district,International Journal of Civil Engineering and Technology,V-8,I-8,PP-1362-1369,Y-2017

25. Arunya A., Sarayu K., Ramachandra Murthy A., Iyer N.R.,Enhancement of durability properties of bioconcrete incorporated with nano silica,International Journal of Civil Engineering and Technology,V-8,I-8,PP-1388-1394,Y-2017
6. Ilayaraja K., Krishnamurthy R.R., Jayaprakash M., Velmurugan P.M. Muthuraj S.,Characterization of the 26 December 2004 tsunami deposits in Andaman Islands (Bay of Bengal, India),Environmental Earth Sciences,V-66,I-8,PP-2459-2476,Y-2012

Ilayaraja K.,Morphometric parameters of micro watershed in Paravanar sub-basin, Cuddalore District,International Journal of Civil Engineering and Technology,V-8,I-8,PP-1444-1449,Y-2017

Ilayaraja K., Singh R.K., Rana N., Chauhan R., Sutradhar N.,Site suitability assessment for residential areas in south Chennai region using remote sensing and GIS techniques,International Journal of Civil Engineering and Technology,V-8,I-8,PP-1468-1475,Y-2017

Ilayaraja K., Reza W., Kumar V., Paul S., Chowdhary R.,Estimation of land surface temperature of Chennai metropolitan area using Landsat images,International Journal of Civil Engineering and Technology,V-8,I-8,PP-1450-1456,Y-2017

Chitra R.,Experimental study on beam using steel fiber and latex,International Journal of Civil Engineering and Technology,V-8,I-8,PP-1395-1403,Y-2017 Chitra R.,Analysis of traffic and management at Kovilambakkam intersection,International Journal of Civil Engineering and Technology,V-8,I-8,PP-1433-1443,Y-2017

Aswathy M.,Experimental study on light weight foamed concrete,International Journal of Civil Engineering and Technology,V-8,I-8,PP-1404-1412,Y-2017 Aswathy M.,Wastewater treatment using constructed wetland with water lettuce (Eichornia Crasipies),International Journal of Civil Engineering and Technology,V-8,I-8,PP-1413-1421,Y-2017

Kiruthiga K., Anandh K.S., Gunasekaran K, Assessment of influencing factors on improving effectiveness and productivity of construction engineers, 2015, International Journal of Applied Engineering Research, V - 10,I -17,p $-13849-13854$.

\section{AUTHORS PROFILE}

Dr R.Venkata Krishnaiah , Associate Professor, Department of Civil Engineering, Bharath Institute of Higher Education and Research, Chennai, India

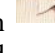

\section{(1)}

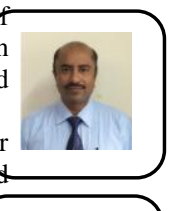

P. Dayakar, Associate Professor, Department of Civil Engineering, Bharath Institute of Higher Education and Research, Chennai, India

Dr. S.J. Mohan, Professor, Department of Civil Engineering, Bharath Institute of Higher Education and Research, Chennai, India 